\title{
Anticancer activity of isolated constituents from Aralia racemosa $L$ and Argyreia pilosa wight \& arn by sulphorhodamine (SRB) assay on ishikawa and SCC- 29B cell Lines
}

\begin{abstract}
Aim: To study the anticancer activity of isolated compounds from root of Aralia racemosa $L$ and whole plant of Argyreia pilosa Wight \& Arn by SRB assay method on Ishikawa human Endometrial Adenocarcinoma and SCC-29B human oral cancer cell lines.

Materials and methods: Anticancer activity of isolated constituents of Aralia racemosa L and Argyreia pilosa Wight \& Arn. was performed on SCC-29B and Ishikawa cancer cell lines by the Advanced Centre for Treatment Research and Education in Cancer (ACTREC) Mumbai, India. Cell line had been developed within RPMI 1640 medium that contains 10\% fetal bovine serum and $2 \mathrm{mM} \mathrm{L-glutamine}$ with the help of SRB assay along with the absorbance had been recorded on an Elisa plate reader at a wavelength of $540 \mathrm{~nm}$ with $690 \mathrm{~nm}$.
\end{abstract}

Results: Isolated constituents particularly caffeic acid showed LC50, TGI and GI50 activity at $>80,69.7$ and $<10 \mu \mathrm{g} / \mathrm{ml}$ on Ishikawa and $>80 \mu \mathrm{g} / \mathrm{ml}$ of GI50 activity on SCC-29B cell lines; Ursolic acid showed TGI and GI50 activity at 37.2 and $<10 \mu \mathrm{g} /$ $\mathrm{ml}$ on Ishikawa and $60.2,<10$ and $<10 \mu \mathrm{g} / \mathrm{ml}$ of LC50, TGI and GI50 activity on SCC29B cell lines respectively.

Conclusion: Ursolic acid from Aralia racemosa $L$ and Caffeic acid from Argyreia pilosa Wight \& Arn has been showed anticancer activity SCC-29B and Ishikawa cancer cell line has been showed potent anticancer activity.

Keywords: Aralia racemosa L, Argyreia pilosa wight \& arn, ishikawa, SCC-29B, ursolic acid, caffeic acid
Volume 5 Issue I - 2018

\author{
Prasanth DSNBK,' Srinivasa Rao A, ${ }^{2}$ \\ Rajendra Prasad $Y^{3}$ \\ 'Department of Pharmacy, JNTUK, India \\ 2Department of Pharmaceutical Analysis and Quality Control, \\ ShriVishnu College of Pharmacy, India \\ ${ }^{3}$ Department of Pharmaceutical chemistry, University College of \\ Pharmaceutical Sciences, India
}

Correspondence: Prasanth DSNBK, Department of Pharmacy, INTUK, Kakinada-533 003, Andhra Pradesh, India, Tel +9|

7382027437,Email dsnbkprasanth@gmail.com

Received: December 10, 2017 | Published: January 02, 2018
Abbreviations: ACTREC, advanced centre for treatment research and education in cancer; PEE, petroleum ether extract; SRB, sulforhodamine B; TGI, total growth inhibition; TCA, tricyclic antidepressant

\section{Introduction}

A significant part of drug discovery in the last forty years has been focussed on agents to prevent or treat cancer. This is not surprising because, in most developed countries and, to an increasing extent, in developing countries, cancer is amongst the three most common causes of death and morbidity. Treatments for cancer may involve surgery, radiotherapy and chemotherapy and often a combination of two or all three is employed. Natural compounds from flowering plants play a significant role in cancer chemotherapy. Anticancer drugs in wide clinical use include vincristine and vinblastine from Catharanthus roseus, palitaxel (Taxol) and taxotere from species of yew (Taxus), etoposide derived from lignans of Podophyllum spp. and camptothecin analogues, such as topotecan, from Camptotheca acuminata. All of these are fundamentally cytotoxic and act principally by inhibiting cell proliferation, but by different mechanisms. In fact, some natural products have been found to act by novel mechanisms and so have enabled novel targets to be developed for screening, exemplified by the discovery that paclitaxel inhibited mitosis by stabilising microtubules and so preventing their depolymerisation back to tubulin, in contrast to many other anticancer agents which inhibit the formation of microtubules in the first place.

Araliaceae is an extensive family consists of 254 species. Aralia racemosa $L$. is a perennial herb in this family and is distributed in America, Africa, Australia, New Zealand and Pacific Islands. The genus Aralia of the family Araliaceae is contained up of 71 species of plants scattered over Asia, North America and South America i.e., A. armata, A. bipinnata, A. chinensis, $A$. continentalis, $A$. cordata, $A$. dasyphylla, A. echinocaulis, A. elata, A. fargensii, A. nudicaulis. One genus of Aralia found in India i.e., Aralia racemosa $L$. It is commonly known as American Spikenard. The plants of this family have a significant contribution in the treatment of respiratory inflammation, diabetes, cancer, and parasitic infections. ${ }^{2}$ The genus Aralia is rich in triterpenoidal saponins chemically. Phytochemical investigation on Aralia racemosa $L$. revealed the presence of triterpenoidal saponins i.e., Oleanolic Acid, Sterols i.e., $\beta$-sitosterol and Diterpenoids i.e., ent-Kaurenoic acid, Continentalic acid. ${ }^{2,3}$ In conventional system of medicine the various parts of $A$. racemosa $L$. can be used in the remedy of Rheumatism, Whooping cough, skin diseases, pleurisy, diaphoretic, diuretic, pulmonary diseases, asthma, rheumatism, diarrhea, stimulant, expectorant, syphilis, Inflammation and Hay fever. ${ }^{4,5}$ Various pharmacological activities of Aralia racemosa have 
been reported such as antioxidant, ant diabetic, ${ }^{6,7}$ anti tubercular ${ }^{8}$ and hepatoprotective. ${ }^{9}$

Argyreia pilosa Wight \& Arn is an ornamental, in addition to a medicinal plant. All parts of this plant are widely used as a folklore medicine for the treatment of various ailments by the Indian traditional healer. Its root is utilized to cure a various illness like sexually transmitted diseases viz., gonorrhea and syphilis, blood diseases. Traditionally, the paste of the leaves is applied to the neck region for cough, quinsy and applied externally in case of itch, eczema and other skin troubles, antidiabetic, antiphlogistic, rheumatism and reduce burning sensation. ${ }^{10}$ Young wines are mixed together with rhizome of ginger are spread all around the body to relieve from fever. The decoction of its root used to treat diarrhea and cathartic. ${ }^{11}$ A vast range of phytochemical constituents has been separated from the genus Argyreia i.e., glycosides, alkaloids, amino acids, proteins, flavonoids, triterpene and steroids. ${ }^{12}$ The genus Argyreia has been reported various biological activities including nootropic, aphrodisiac, antioxidant, antiulcer, immunomodulatory, hepatoprotective, anti-inflammatory, antihyperglycemic, antidiarrheal, antimicrobial, antiviral, nematicidal, anticonvulsant, analgesic, anti-inflammatory, wound healing, anthelmintic and central nervous depressant activities. ${ }^{12-14}$ Even though the drug has many uses, it's pharmacological and phytochemistry is very poorly explored. Traditionally, both plants were utilized for anticancer activity but till date no scientific evidence has been reported on SCC-29B and Ishikawa cancer cell lines. Therefore, the current study has been carried out with the isolated constituents from root of Aralia racemosa L. and whole plant of Argyreia pilosa Wight and Arn. with a view to investigate its anticancer activity against SCC-29B and Ishikawa cancer cell lines using adriamycin as a reference standard.

\section{Materials and methods}

\section{Procurement and authentication of crude drug}

The plants $A$. racemosa and A. pilosa were collected from Tirupath during the month of September, 2016. The plants were identified and authenticated by Dr K. Madhava chetty; plant taxonomist, Department of Botany, Sri Venkateswara University, Tirupati, Andhra Pradesh and voucher specimen of the plant (No 1489 and 1922) were deposited at the herbarium for future references. The plant materials were dried under shade for 15 days, coarsely powdered and stored in air tight containers protected from humidity and sunlight for further study.

\section{Preparation of methanolic extracts}

Each $250 \mathrm{~g}$ of powdered crude drug of $A$. racemosa and A. pilosa were extracted by cold maceration with $1000 \mathrm{~mL}$ of methanol for $18 \mathrm{~h}$. The extracts acquired were concentrated to dryness in vacuum at $40^{\circ} \mathrm{C}$ and stored at $4^{\circ} \mathrm{C}$ within the refrigerator until further used. The extracts were subjected to phytochemical and pharmacological assessment. $^{15}$

\section{Phytochemical screening}

The various extracts of $A$. racemosa and A. pilosa were subjected to qualitative chemical analysis by using standard procedures as follows. The phytochemical screening of carbohydrates was detected by Molisch's test; proteins were detected by using two tests namely Biuret test and Millon's test and amino acids by Ninhyrdin's test; Steroids was detected by Salkowski, Liebermann- Bur chard's and Liebermann's test; alkaloids were identified with freshly prepared
Dragendroff's Mayer's, Hager's and Wagner's reagents and observed for the presence of turbidity or precipitation. The flavonoids were detected using four tests namely Shinoda, sulfuric acid, aluminum chloride, lead acetate, and sodium hydroxides. Tannins were detected with four tests namely gelatin, lead acetate, potassium dichromate and ferric chloride. The froth, emulsion, and lead acetate tests were applied for the detection of saponins. The steroids were detected by (acetic anhydride with sulfuric acid) and (acetic chloride with sulfuric acid) tests. Sample extracted with chloroform was treated with sulfuric acid to test for the presence of terpenoids. Ammonia solution and ferric chloride solutions were used for the presence of anthraquionones. ${ }^{16-23}$

\section{Isolation of constituents from Aralia racemosa $L$.}

Petroleum ether extract (PEE) was subjected to silica-gel (100$200 \mathrm{mesh}$ ) column (length $100 \mathrm{~cm}$ and diameter $3 \mathrm{~cm}$ ) chromatography (elution rate of $2 \mathrm{ml} \mathrm{min}^{-1}$ flow with a total elution of $200 \mathrm{ml}$ ) and eluted with Petroleum ether and ethyl acetate in different proportions. The consequent fractions $(\mathrm{Fr})$ were collected and spotted over pre-coated silica gel F254 plates $(20 \times 20 \mathrm{~cm}$, Merck, Germany). The optimum resolution was achieved in the hexane, ethyl acetate and formic acid $(7.5: 2: 0.5 \mathrm{v} / \mathrm{v})$ solvent system and the plates were sprayed with anisaldehyde-sulphuric acid reagent to visualize the spots. The fractions showing similar spots were pooled together and concentrated. The fractions which showed prominent spots were taken up for spectral studies which result in the identification of 3 compounds. The compounds PC -2 was identified as Stigmasterol, a phytosterols by Libermann-Burchard's test. The chloroform fraction was subjected to chromatography on silica gel (60-120 mesh, Merck) eluted with ethyl acetate-hexane (7:3) solvent system. Repeated chromatography to give major two pentacyclic triterpenoids i.e., $\mathrm{PC}-4$ and PC -5 i.e. Oleanolic acid and Ursolic acid..$^{24,25}$

\section{Isolation of constituents from Argyreia pilosa wight \& arn}

Petroleum ether extract (PEE) was subjected to silica-gel column chromatography (elution rate of $2 \mathrm{ml} \mathrm{min}^{-1}$ flow having a total elution of $200 \mathrm{ml}$ ) and eluted with Petroleum ether and ethyl acetate in various ratios. The resulting fractions $(\mathrm{Fr})$ were obtained and spotted over precoated silica gel F254 plates $(20 \times 20 \mathrm{~cm}$, Merck, Germany). The best resolution had been attained using chloroform: ethyl acetate $(5: 5 \mathrm{v} / \mathrm{v})$ solvent system as well as the plates was dribbled using anisaldehyde-sulphuric acid reagent to visualize the spots. The chloroform portion was subjected to chromatography on silica gel (60-120 mesh, Merck) elided with chloroform: ethyl acetate (5:5) solvent system. Repeated chromatography to provide two main steroids i.e., $\mathrm{PC}-1$ ( $\beta$-Sitosterol) and $\mathrm{PC}-2$ (Stigmasterol). ${ }^{26}$ Soon after extraction, the aqueous portion was attained and leftover to stand in a cool place for 72 hours; a yellow coloured product separated from the solution. The precipitate was filtered and washed with a combination of chloroform: ethyl acetate: ethanol $(50: 25: 25)$. The un-dissolved portion of the precipitate was mixed in hot methanol strained, the filtrate was evaporated to dryness to provide $115 \mathrm{mg}$ yellow powder i.e., $\mathrm{PC}-1$ (Rutin), and its melting point had been determined. The ethyl acetate fraction was chromatographed using Diaion HP eluted from water-methanol step gradient (Starting from 100:0 to 0:100). The water-methanol fraction (50:50) had been chromatographed on sephadex LH-20 column eluted with methanol: water (7:3) to give PC-2 (Caffeic acid). ${ }^{27}$ 


\section{Anticancer activity on ishikawa and SCC-29B cell lines}

The anticancer activity of isolated constituents of Aralia racemosa L. and Argyreia pilosa Wight \& Arn was performed on Ishikawa SCC-29B and cancer cell lines by the Advanced Centre for Treatment Research and Education in Cancer (ACTREC) Mumbai, India. The cell viability was measured using SRB assay. All the environmental conditions were maintained throughout the experiment for all the groups. The assay was performed in triplicate for each of the extracts. The growth curve was plotted against molar drug concentration of isolated constituents and \% control growth.

\section{Experimental procedure or SRB assay}

The cell lines were grown in RPMI 1640 medium containing 10\% fetal bovine serum and $2 \mathrm{mM} \mathrm{L}$-glutamine. For present screening experiment, cells were inoculated into 96 well microtiter plates in $100 \mu \mathrm{L}$ at plating densities as shown in the study details above, depending on the doubling time of individual cell lines. After cell inoculation, the microtiter plates were incubated at $37^{\circ} \mathrm{C}, 5 \% \mathrm{CO}_{2}$, $95 \%$ air and $100 \%$ relative humidity for $24 \mathrm{~h}$ prior to addition of experimental drugs. Experimental drugs were initially solubilized in dimethyl sulfoxide at $100 \mathrm{mg} / \mathrm{ml}$ and diluted to $1 \mathrm{mg} / \mathrm{ml}$ using water and stored frozen prior to use. At the time of drug addition, an aliquote of frozen concentrate $(1 \mathrm{mg} / \mathrm{ml})$ was thawed and diluted to $100 \mu \mathrm{g} / \mathrm{ml}$, $200 \mu \mathrm{g} / \mathrm{ml}, 400 \mu \mathrm{g} / \mathrm{ml}$ and $800 \mu \mathrm{g} / \mathrm{ml}$ with complete medium containing test article. Aliquots of $10 \mu 1$ of these different drug dilutions were added to the appropriate microtiter wells already containing $90 \mu \mathrm{l}$ of medium, resulting in the required final drug concentrations i.e. $10 \mu \mathrm{g} /$ $\mathrm{ml}, 20 \mu \mathrm{g} / \mathrm{ml}, 40 \mu \mathrm{g} / \mathrm{ml}, 80 \mu \mathrm{g} / \mathrm{ml}$.

After compound addition, plates were incubated at standard conditions for 48 hours and assay was terminated by the addition of cold TCA. Cells were fixed in situ by the gentle addition of $50 \mu 1$ of cold 30\% (w/v) TCA (final concentration, 10\% TCA) and incubated for 60 minutes at $4^{\circ} \mathrm{C}$. The supernatant was discarded; the plates were washed five times with tap water and air dried. Sulforhodamine B (SRB) solution $(50 \mu 1)$ at $0.4 \%(\mathrm{w} / \mathrm{v})$ in $1 \%$ acetic acid was added to each of the wells, and plates were incubated for 20 minutes at room temperature. After staining, unbound dye was recovered and the residual dye was removed by washing five times with $1 \%$ acetic acid. The plates were air dried. Bound stain was subsequently eluted with $10 \mathrm{mM}$ trizma base, and the absorbance was read on an plate reader at a wavelength of $540 \mathrm{~nm}$ with $690 \mathrm{~nm}$ reference wavelength. Percent growth was calculated on a plate-by-plate basis for test wells relative to control wells. Percent Growth was expressed as the ratio of average absorbance of the test well to the average absorbance of the control wells $* 100$. Using the six absorbance measurements [time zero (Tz), control growth (C), and test growth in the presence of drug at the four concentration levels (Ti)]; the percentage growth was calculated at each of the drug concentration levels.

\section{Percentage growth inhibition $=$ For concentrations for which $T i>/=T z(T i-T z)$ positive or zero $=[(T i-T z) /(C-T z)] \times 100$}

For concentrations for which

$$
T i>/=T z(T i-T z) \text { positiveor zero }=[(T i-T z) /(C-T z)] \times 100
$$

For concentrations for which

$$
T i<T z(T i-T z) \text { negative }=[(T i-T z) /(C-T z)] \times 100
$$

Growth inhibition of $50 \%$

$$
G 150=[(T i-T z) /(C-T z)] \times 100
$$

GI50 is that value of the drug concentration resulting in a $50 \%$ reduction in the net protein increase (as measured by SRB staining) in control cells during the drug incubation. The drug concentration resulting in total growth inhibition (TGI) was calculated from $\mathrm{Ti}=\mathrm{Tz}$. The LC50 is the drug concentration resulting in a $50 \%$ reduction in the measured protein at the end of the drug treatment as compared to that at the beginning. During this there is a net loss of $50 \%$ cells following treatment is calculated from

$$
[(T i-T z) / T z] \times 100=-50 \cdot{ }^{28,29}
$$

\section{Statistical analysis}

Values were calculated for each of these three parameters if the level of activity was reached; however, if the effect was not reached or was exceeded, the values for that parameter were expressed as greater or less than the maximum or minimum concentration tested. The experiment data were estimated using linear regression method of plots of the cell viability against the molar drug concentration of tested compounds.

\section{Results and discussion}

\section{Phytochemical screening}

The phytochemical screening for various extracts viz., petroleum ether, chloroform, ethyl acetate, methanol, n-butanol, and water was carried out and results were displayed in (Table $1 \& 2$ ).

\section{Characterization of isolated phytoconstituents from Aralia racemosa and Argyreia pilosa}

\section{stigmasterol}

White powder, $\mathrm{C}_{29} \mathrm{H}_{48} \mathrm{O}$, MW 412.69. UV $\lambda_{\text {max }}\left(\mathrm{CHCl}_{3}\right) \mathrm{nm}$ : 257; IR $(\mathrm{KBr}) v_{\max } 3418(-\mathrm{OH}), 2934,2866,2339,1602,1566,1461,1409$, 1383, 1251, 1191, 1154, 1109, 1089, 1053, 1020, 791 $\mathrm{cm}^{-1}$; ESMS m/z (\%): 409.2, 395.3, 335, 161, 144, 121.1, 105.1, 97.1, 85.1, 69, $67.2,65,50.2 ; 1 \mathrm{H} \mathrm{NMR}\left(400 \mathrm{MHz}, \mathrm{CDCl}_{3}\right) \delta_{\mathrm{ppm}}: 7.25(1 \mathrm{H}, \mathrm{s}, \mathrm{OH}-2)$, 5.34-5.35 (1H, d), 5.12-5.18 (1H, m), 4.99-5.05 (1H, m), 3.48-3.56 $(1 \mathrm{H}, \mathrm{m}), 2.18-2.31(2 \mathrm{H}, \mathrm{m}), 1.93-2.09(3 \mathrm{H}, \mathrm{m}), 1.82-1.87(2 \mathrm{H}, \mathrm{m})$, $1.66-1.75(1 \mathrm{H}, \mathrm{m}), 1.37-1.54(13 \mathrm{H}, \mathrm{m}), 1.05-1.31(\mathrm{~m}, 7 \mathrm{H}), 0.99$ $1.01(\mathrm{~m}, 8 \mathrm{H}), 0.90-0.98(\mathrm{~m}, 2 \mathrm{H}), 0.78-0.85(\mathrm{~m}, 9 \mathrm{H}), 0.66-0.70(3 \mathrm{H}$, t); ${ }^{13} \mathrm{C}$ NMR $\left(400 \mathrm{MHz}, \mathrm{CDCl}_{3}\right) \delta_{\mathrm{ppm}}: 140.85(\mathrm{C}-4), 138.31(\mathrm{C}-19)$, 129.40 (C-20), 121.72 (C-7), 77.34 (C-2), 71.86 (C-11), 56.95 (C17), 56.09 (C-21), 51.29 (C-10), 50.29 (C-12), 42.41 (C-3), 42.30 (C-18), 40.46 (C-13), 39.77 (C-5), 37.35 (C-6), 36.59 (C-8), 32 (C-9), 31.96 (C-1), 31.91 (C-22), 31.77 (C-16), 28.91 (C-15), 25.41 (C-24), 24.41 (C-23), 21.24 (C-26), 21.14 (C-14), 21.06 (C-29), 19.42 (C-27), 19.03 (C-25), 12.23 (C-28). PC-01 was identified as Stigmasterol.

\section{Oleanolic acid}

White powder, $\mathrm{C}_{30} \mathrm{H}_{48} \mathrm{O}_{3}$, MW 456.71; UV $\lambda_{\max }(\mathrm{EtOH}) \mathrm{nm}: 210$; 
IR (KBr) $v_{\text {max }} 3443,2941,2862,1694,1602,1566,1462,1388,1364$, 1304, 1273, 1208, 1185, 1161, 1093, 1028, 960, 791 $\mathrm{cm}^{-1} ;$ ESMS m/z (\%): 455.3, 456.2; $1 \mathrm{H}$ NMR (400MHz, DMSO) $\delta_{\mathrm{ppm}}: 12(1 \mathrm{H}, \mathrm{s}), 5.16$ $(1 \mathrm{H}, \mathrm{s}), 4.27(1 \mathrm{H}, \mathrm{s}), 3(1 \mathrm{H}, \mathrm{s}), 2.73-2.77(1 \mathrm{H}, \mathrm{m}), 1.88-1.95(1 \mathrm{H}$ s), $1.80-1.83(2 \mathrm{H}, \mathrm{m}), 1.58-1.70(3 \mathrm{H}, \mathrm{m}), 1.42-1.50(8 \mathrm{H}, \mathrm{m}), 1.23-$ $1.38(5 \mathrm{H}, \mathrm{m}), 1.07-1.10(4 \mathrm{H}, \mathrm{t}), 0.98-1.01(1 \mathrm{H}, \mathrm{m}), 0.86-0.93(14 \mathrm{H}$, $\mathrm{m}), 0.72(3 \mathrm{H}, \mathrm{s}), 0.68(5 \mathrm{H}, \mathrm{s}) ;{ }^{13} \mathrm{C}$ NMR $(400 \mathrm{MHz}) 178.52(\mathrm{C}-28)$,
143.83 (C-12), 121.49 (C-13), 76.83 (C-2), 54.81 (C-4), 47.09 (C11), 45.70 (C-10), 45.44 (C-22), 41.32 (C-17), 40.82 (C-22), 40.20 (C-18), 39.99 (C-12), 39.58 (C-9), 39.37 (C-6), 39.16 (C-3), 38.95 (C-5), 38.89 (C-8), 38.36 (C-19), 38.07 (C-21), 36.60 (C-1), 33.34 (C-29), 32.80 (C-30), 32.43 (C-16), 32.09 (C-14), 30.35 (C-23), 28.21 (C-24), 27.20 (C-7), 26.94 (C-26), 14.82 (C-27). PC-04 was identified as Oleanolic acid.

Table I Phytochemical screening of successive solvent extraction of Aralia racemosa $L$

\begin{tabular}{|c|c|c|c|c|c|c|}
\hline Phytoconstituents & Method & $\begin{array}{l}\text { Aqueous } \\
\text { extract }\end{array}$ & $\begin{array}{l}\text { Methanolic } \\
\text { extract }\end{array}$ & $\begin{array}{l}\text { Ethyl acetate } \\
\text { extract }\end{array}$ & $\begin{array}{l}\text { Chloroform } \\
\text { extract }\end{array}$ & $\begin{array}{l}\text { Pet. ether } \\
\text { extract }\end{array}$ \\
\hline \multirow[t]{3}{*}{ Flavonoids } & Shinoda Test & + & + & + & - & - \\
\hline & Zn. Hydrocholride Test & + & + & + & - & - \\
\hline & Lead acetate Test & + & + & + & - & - \\
\hline Volatile Oil & Stain Test & - & + & - & - & - \\
\hline \multirow[t]{2}{*}{ Alkaloids } & Wagner Test & - & - & - & - & - \\
\hline & Hager's Test & - & - & - & - & - \\
\hline \multirow[t]{2}{*}{ Tannins \& Phenols } & Fecl3 Test & + & + & - & + & - \\
\hline & Potassium Dichromate Test & + & + & - & + & - \\
\hline Saponins & Foaming Test & + & + & - & - & - \\
\hline Steroids & Salkowski Test & + & + & - & - & + \\
\hline Carbohydrates & Molish Test & - & - & - & - & - \\
\hline Acid Compounds & Litmus Test & - & - & - & - & - \\
\hline Glycoside & Keller-Killani Test & + & + & - & - & - \\
\hline Amino Acids & Ninhydrin Test & - & - & - & - & - \\
\hline Proteins & Biuret & - & - & - & - & - \\
\hline
\end{tabular}

“+”: Present;"“”:Absent

Table 2 Phytochemical screening of successive solvent extraction of Argyreia pilosa

\begin{tabular}{|c|c|c|c|c|c|}
\hline Phytoconstituents & Method & $\begin{array}{l}\text { Pet. ether } \\
\text { extract }\end{array}$ & $\begin{array}{l}\text { Ethyl acetate } \\
\text { extract }\end{array}$ & $\begin{array}{l}\text { Chloroform } \\
\text { extract }\end{array}$ & Methanol extract \\
\hline \multirow[t]{3}{*}{ Flavonoids } & Shinoda Test & - & + & - & + \\
\hline & Zn. Hydrochloride Test & - & + & - & + \\
\hline & Lead acetate Test & - & + & - & + \\
\hline Volatile Oil & Stain Test & - & - & - & - \\
\hline \multirow[t]{2}{*}{ Alkaloids } & Wagner Test & - & - & + & + \\
\hline & Hager's Test & - & - & + & + \\
\hline \multirow[t]{2}{*}{ Tannins \& Phenols } & $\mathrm{FeCl} 3$ Test & - & + & - & + \\
\hline & Potassium Dichromate Test & - & - & - & + \\
\hline Saponins & Foaming Test & - & - & - & - \\
\hline Steroids & Salkowski Test & + & - & + & + \\
\hline Fixed Oils and Fats & Spot Test & + & - & - & - \\
\hline Carbohydrates & Molish Test & - & - & - & + \\
\hline Acid Compounds & Litmus Test & - & - & - & + \\
\hline Glycoside & Keller-Killani Test & - & - & - & + \\
\hline Amino Acids & Ninhydrin Test & - & - & - & + \\
\hline Proteins & Biuret & - & - & - & + \\
\hline
\end{tabular}

“+”: Present;“-”:Absent 


\section{Ursolic acid}

White powder, C30H48O3, MW 456.7 ; UV $\lambda_{\max }(\mathrm{EtOH}) \mathrm{nm}: 203$ IR $(\mathrm{KBr}) v_{\max } 3450,2925,2869,2339,1556,1456,1387,1247,1157$ $822,444,433,422,415 \mathrm{~cm}^{-1}$; ESMS m/z (\%): $455.2(\mathrm{M}-1)+, 456.2$, 457.3; $1 \mathrm{H}$ NMR (400MHz, DMSO) $\delta_{\mathrm{ppm}}: 11.91(1 \mathrm{H}, \mathrm{s}), 5.14(1 \mathrm{H}, \mathrm{s})$, $4.27(1 \mathrm{H}, \mathrm{s}), 3.01(1 \mathrm{H}, \mathrm{s}), 2.51(1 \mathrm{H}, \mathrm{s}), 2.10-2.13(1 \mathrm{H}, \mathrm{d}) 1.85-1.93$ $(4 \mathrm{H}, \mathrm{t}), 1.26-1.32(4 \mathrm{H}, \mathrm{t}), 1.05(1 \mathrm{H}, \mathrm{s}), 0.91-0.92(8 \mathrm{H}, \mathrm{d}), 0.88(1 \mathrm{H}$, s) $0.82-0.83(4 \mathrm{H}, \mathrm{d}), 0.76(3 \mathrm{H}, \mathrm{s}), 0.69(4 \mathrm{H}, \mathrm{s}) ;{ }^{13} \mathrm{C} \mathrm{NMR}(400 \mathrm{MHz}$, DMSO) $\delta_{\text {ppm }}: 178.16$ (C-29), 138.17 (C-12), 124.58 (C-13), 76.86 (C-2), 56.01 (C-4), 54.82 (C-18), 52.40 (C-11), 47.05 (C-10), 46.82 (C-17), 41.64 (C-9), 40.41 (C-3), 40.21 (C-22), 40 (C-6), 39.79 (C-5), 39.58 (C-19), 39.37 (C-8), 39.16 (C-20), 38.96 (C-1), 38.49 (C-15), 38.46 (C-16), 38.36 (C-23), 38.28 (C-24), 36.53 (C-14), 36.31 (C-30), 32.73 (C-7), 30.2 (C-28), 28.24 (C-26), 27.55 (C-27), 26.99 (C-15). PC-03 was identified as Ursolic acid.

\section{Rutin}

Yellow powder, C27H30O16, MW 610.52; UV $\lambda_{\text {max }}(\mathrm{EtOH}) \mathrm{nm}$ : 203; IR (KBr) $v_{\text {max }} 1001,1013,1065,1092,1150,1166,1203,1295$, $1362,1458,1504,1566,1601,1649,2340,3422 \mathrm{~cm}^{-1}$; ESMS m/z (\%): 609.1 (M-1)-, 610, 301; 1H NMR (400MHz, DMSO) $\delta_{\mathrm{ppm}}: 12.6(1 \mathrm{H}$, s), $10.84(1 \mathrm{H}, \mathrm{s}), 9.68(1 \mathrm{H}, \mathrm{s}), 9.18(1 \mathrm{H}, \mathrm{s}), 7.55-7.56(1 \mathrm{H}, \mathrm{d}), 7.54$ $(1 \mathrm{H}, \mathrm{s}) 6.84-6.86(1 \mathrm{H}, \mathrm{d}), 6.39(1 \mathrm{H}, \mathrm{d}), 6.2(1 \mathrm{H}, \mathrm{d}), 5.34-5.36(1 \mathrm{H}, \mathrm{t})$, $5.29(1 \mathrm{H}, \mathrm{d}), 5.11(1 \mathrm{H}, \mathrm{s}), 5.07-5.09(1 \mathrm{H}, \mathrm{d}), 4.53(1 \mathrm{H}, \mathrm{s}), 4.39(2 \mathrm{H}$, s). $4.35(1 \mathrm{H}, \mathrm{s}), 3.70-3.72(1 \mathrm{H}, \mathrm{d}), 3.21-3.32(1 \mathrm{H}, \mathrm{m}), 3.05-3.10(2 \mathrm{H}$, t); 13C NMR (400MHz, DMSO) $\delta_{\text {: }}: 177.35(\mathrm{C}-4), 164.03(\mathrm{C}-7)$, 161.20 (C-5), 156.57 (C-8a), 156.40 (C-2), 148.37 (C-4'), 144.71 (C-5'), 133.31 (C-3), 121.56 (C-1'), 121.18 (C-2'), 116.26 (C-3'), 115.21 (C-6'), 103.96 (C-6"'), 101.19 (C-6"), 100.70 (C-4a), 98.65 (C-6), 93.55 (C-8), 76.46 (C-2"), 75.90 (C-4”), 74.06 (C-5"), 71.85 (C-2"'), 70.56 (C-5"'), 70.35 (C-3"'), 70.01 (C-4"'), 68.20 (C-3"), 66.97 (C-2a), 17.68 (C-2"'). PC-03 was identified as Rutin.

\section{Caffeic acid}

White powder, C9H8O4; MW 180.16 ; UV $\lambda_{\text {max }}$ (Acidified $\mathrm{MeOH}): 295 \mathrm{~nm}$; IR (KBr) $v_{\max } 960.11,1118,1156,1217,1278,1295$, 1326, 1353, 1449, 1566, 1602, 2350 and $3424 \mathrm{~cm}^{-1}$; ESMS m/z (\%): $177,178,179$ (M-1), 180, 135.2; 1H NMR (400MHz, DMSO) $\delta_{\mathrm{ppm}}$ : $3.41(1 \mathrm{H}, \mathrm{s}), 6.15-6.19(1 \mathrm{H}, \mathrm{d}), 6.75-6.77(1 \mathrm{H}, \mathrm{s}), 6.95-6.98(1 \mathrm{H}, \mathrm{q})$, 7.031-7.035 (1H, d), 7.4-7.44 (1H, d), 9.12 (1H, s), 9.51 (1H, s), 12.1 $(1 \mathrm{H}, \mathrm{s}) ;{ }^{13} \mathrm{C}$ NMR $(400 \mathrm{MHz}, \mathrm{DMSO}) \delta_{\mathrm{ppm}}: 114.63(\mathrm{C}-6), 115.12(\mathrm{C}-$ 8), $115.74(\mathrm{C}-3), 121.08(\mathrm{C}-4), 125.71^{\mathrm{ppm}}(\mathrm{C}-5), 144.52(\mathrm{C}-7), 145.53$ (C-1), 148.08 (C-2), 167.81 (C-9) (Figure 1).

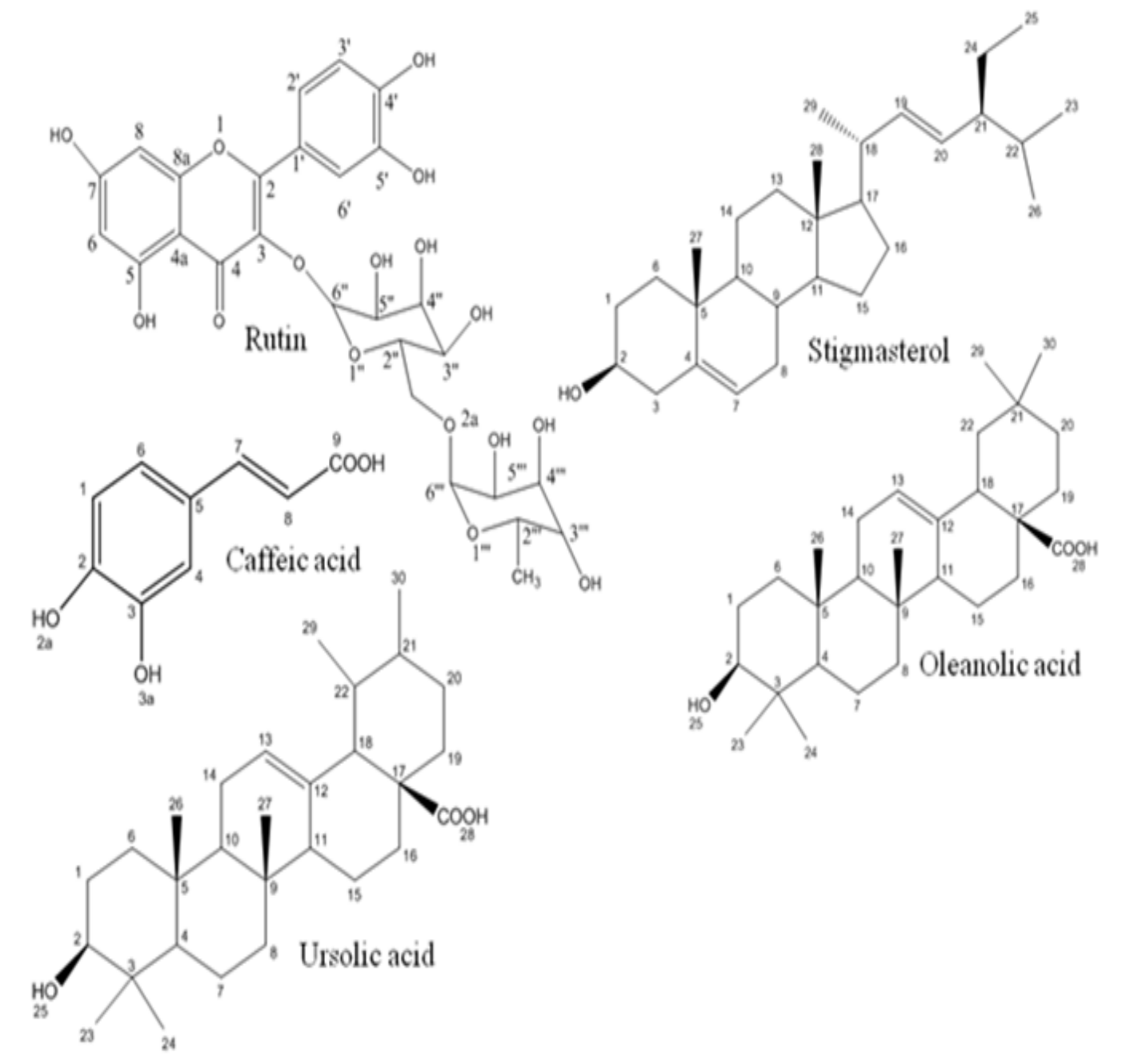

Figure I Isolated constituents from A. racemosa and A. pilosa. 


\section{Anticancer activity}

In the present investigation the cytotoxicity and anticancer activity (in vitro) of isolated constituents from A. racemosa and A. pilosa were carried out on Ishikawa (human endometrial adenocarcinoma cell lines) and SCC-29B (Human oral cancer cell lines) by SRB assay. After completion of protocol the absorbance was read on an Elisa plate reader at a wavelength of $540 \mathrm{~nm}$. Photography of cell cultures were taken Figure 2, Figure 3 and values were plotted on graph and LC50, TGI and GI50 were then calculated from the graph Figure 4. Along with adrinamycin and isolated constituents treated cells also showed kariolysis, apoptosis, roundening of cell Figure 2, Figure

Table 3 Drug concentrations $(\mu \mathrm{g} / \mathrm{ml})$ and percentage of growth inhibition on Ishikawa cell lines
4. GI50 means the drug concentration resulting in a $50 \%$ reduction in the net protein increase as compared to control cells. TGI is the drug concentration resulting in total growth inhibition. The LC50 is the drug concentration resulting in a $50 \%$ reduction in the measured protein at the end as compared to the beginning. Isolated constituents particularly caffeic acid showed LC50, TGI and GI50 activity at $>80$, 69.7 and $<10 \mu \mathrm{g} / \mathrm{ml}$ on Ishikawa and $>80 \mu \mathrm{g} / \mathrm{ml}$ of GI50 activity on SCC $-29 \mathrm{~B}$ cell lines; Ursolic acid showed TGI and GI50 activity at 37.2 and $<10 \mu \mathrm{g} / \mathrm{ml}$ on Ishikawa and $60.2,<10$ and $<10 \mu \mathrm{g} / \mathrm{ml}$ of LC50, TGI and GI50 activity on SCC-29B cell lines respectively (Table 3-6).

\begin{tabular}{|c|c|c|c|c|c|c|c|c|c|c|c|c|c|c|c|c|}
\hline \multicolumn{17}{|c|}{$\begin{array}{l}\text { Human endometrial adenocarcinoma cell line ishikawa \% control growth drug } \\
\text { concentrations }(\mu \mathrm{g} / \mathrm{ml})\end{array}$} \\
\hline & \multicolumn{4}{|c|}{$\begin{array}{l}\text { Experiment } \\
\text { I }\end{array}$} & \multicolumn{4}{|c|}{$\begin{array}{l}\text { Experiment } \\
2\end{array}$} & \multicolumn{4}{|c|}{$\begin{array}{l}\text { Experiment } \\
3\end{array}$} & \multicolumn{4}{|c|}{$\begin{array}{l}\text { Average } \\
\text { values }\end{array}$} \\
\hline & 10 & 20 & 40 & 80 & 10 & 20 & 40 & 80 & 10 & 20 & 40 & 80 & 10 & 20 & 40 & 80 \\
\hline Rutin & 136.5 & 186.5 & 195.3 & 149.1 & 106.8 & 110.7 & 118 & 126.6 & 104.7 & 105.6 & 116.8 & 130.1 & 116 & 134.3 & 143.4 & 135.2 \\
\hline Stigmasterol & 157.1 & 168.9 & 169 & 146.5 & 105.8 & 111.5 & 111.6 & 121.5 & 102.7 & 106.3 & 108.9 & 130.3 & 121.8 & 128.9 & 129.9 & 132.8 \\
\hline Caffeic Acid & 122.3 & I47.4 & 109.2 & -27.5 & 105.9 & 110.1 & 71.6 & -35.7 & 102.7 & 110.9 & 66.7 & -32.3 & 110.3 & 122.8 & 82.5 & -31.9 \\
\hline $\begin{array}{l}\text { Oleanolic } \\
\text { Acid }\end{array}$ & 121.3 & 171.3 & 166.1 & 133.5 & 104.4 & II4.4 & 114.9 & 118.6 & 87.5 & 105.8 & 103.5 & 126.4 & 104.4 & 130.5 & 128.2 & $|26|$. \\
\hline Ursolic Acid & 118.2 & 20.1 & 7.9 & -9.6 & 59 & -31.3 & -50.5 & -22.8 & 39.8 & -45.7 & -58.5 & -29.6 & 72.3 & -19 & -33.7 & -20.7 \\
\hline Adriamycin & 4.7 & -2.3 & -26.8 & -35.3 & 9.2 & 1.1 & -19.3 & -35.1 & 1.6 & -7.1 & -28.1 & -38 & 5.2 & -2.7 & -24.7 & -36.1 \\
\hline
\end{tabular}

Table 4 Drug concentrations $(\mu \mathrm{g} / \mathrm{ml})$ and percentage of growth inhibition on SCC-29B cell lines

\begin{tabular}{|c|c|c|c|c|c|c|c|c|c|c|c|c|c|c|c|c|}
\hline & \multicolumn{4}{|c|}{$\begin{array}{l}\text { Experiment } \\
\text { I }\end{array}$} & \multicolumn{4}{|c|}{$\begin{array}{l}\text { Experiment } \\
2\end{array}$} & \multicolumn{4}{|c|}{$\begin{array}{l}\text { Experiment } \\
3\end{array}$} & \multicolumn{4}{|c|}{$\begin{array}{l}\text { Average } \\
\text { values }\end{array}$} \\
\hline & 10 & 20 & 40 & 80 & 10 & 20 & 40 & 80 & 10 & 20 & 40 & 80 & 10 & 20 & 40 & 80 \\
\hline Rutin & 89.7 & 86.8 & 95.4 & 109.8 & 92.2 & 98.9 & 105.8 & 114 & 92 & 105.9 & 139.7 & 114.8 & 91.3 & 97.2 & 113.6 & 112.9 \\
\hline Stigmasterol & 96 & 83.2 & 92.6 & 106.7 & 85.1 & 82.5 & 95 & 102.1 & 95.9 & 100.8 & 104.8 & 109.9 & 92.3 & 88.8 & 97.5 & 106.2 \\
\hline Caffeic Acid & 85.4 & 90.7 & 62 & 56.7 & 84.4 & 82.5 & 95.7 & 33.4 & 94.7 & 88.8 & 92.1 & 51.1 & 88.2 & 87.3 & 83.3 & 47.1 \\
\hline $\begin{array}{l}\text { Oleanolic } \\
\text { Acid }\end{array}$ & 97.9 & 96.2 & 99.6 & 112.4 & 86.4 & 94.2 & 95.3 & 107 & 97.6 & 100.6 & 102.4 & 112.3 & 94 & 97 & 99.1 & 110.5 \\
\hline Ursolic Acid & 1.6 & -38.6 & -73.9 & -65.9 & -3.4 & -34.9 & -58.3 & -46.8 & -23 & -30.9 & -42.4 & -41.8 & -8.3 & -34.8 & -58.2 & -51.5 \\
\hline Adriamycin & -73.9 & -77.2 & -77.8 & -66.1 & -72.6 & -77.7 & -78.7 & -63.3 & -74.9 & -76.4 & -77.3 & -62 & -73.8 & -77.1 & -77.9 & -63.8 \\
\hline
\end{tabular}

The chemotherapeutic agents extensive utilized in oncologic therapy produce deleterious unwanted effects which enhance the fatality as well as morbidity brought on by malignancy. Safer therapies are thus frantically required, a few of that you can get within natural substances like phytochemicals. Having well-known chemopreventive activities and preclinical antitumor effects, phytochemicals give a novel restorative strategy which value additional exploration. ${ }^{30}$ Phenols and polyphenols, flavonoids and their derivatives, are ubiquitous in plants and more than 8,000 different compounds are included in this group and many of them are antioxidants. They are associated with the inhibition of vascular disease and malignancy. ${ }^{31}$ Flavonoids have drawn a lot of interest with regards to their potential benefits on health. ${ }^{32}$ Flavonoids have been shown to possess antimalignant effects. ${ }^{33}$ In accordance with Gali et al..$^{34}$ the anticancer effects of methanol extract of Argemone mexicana Linn. leaves might be related to their content of Flavonoids. ${ }^{34}$ Reported by Pradhan, flavonoids might exert their chemopreventive role in malignancy via their results on signal transduction in cell proliferation as well as angiogenesis. ${ }^{35}$

Results from present investigation indicate that $A$. racemosa and A. pilosa has anticancer activity (in vitro) on Ishikawa and SCC-29B cancer cell line. The isolated constituents throughout the studies showed negative activity on cell lines except Caffeic acid and Ursolic acid that showed comparable activity to the standard compound Adriamycin for Ishikawa, human Endometrial Adenocarcinoma and SCC-29B, human oral cancer cell lines respectively. The effective concentration of major isolated constituents was observed to be $<80 \mu \mathrm{g} / \mathrm{ml}$. Our results are in concordance with some of the previous studies on this plant. Clement et al. ${ }^{36} \mathrm{MCF}-7$ breast tumor cell line. These previous studies indicate that this plant has some phytochemicals which can 
have possible anticancer activity, either singly or in combination. The present results, together with previous studies, suggest that $A$. racemosa and $A$. pilosa possess anticancer activity.
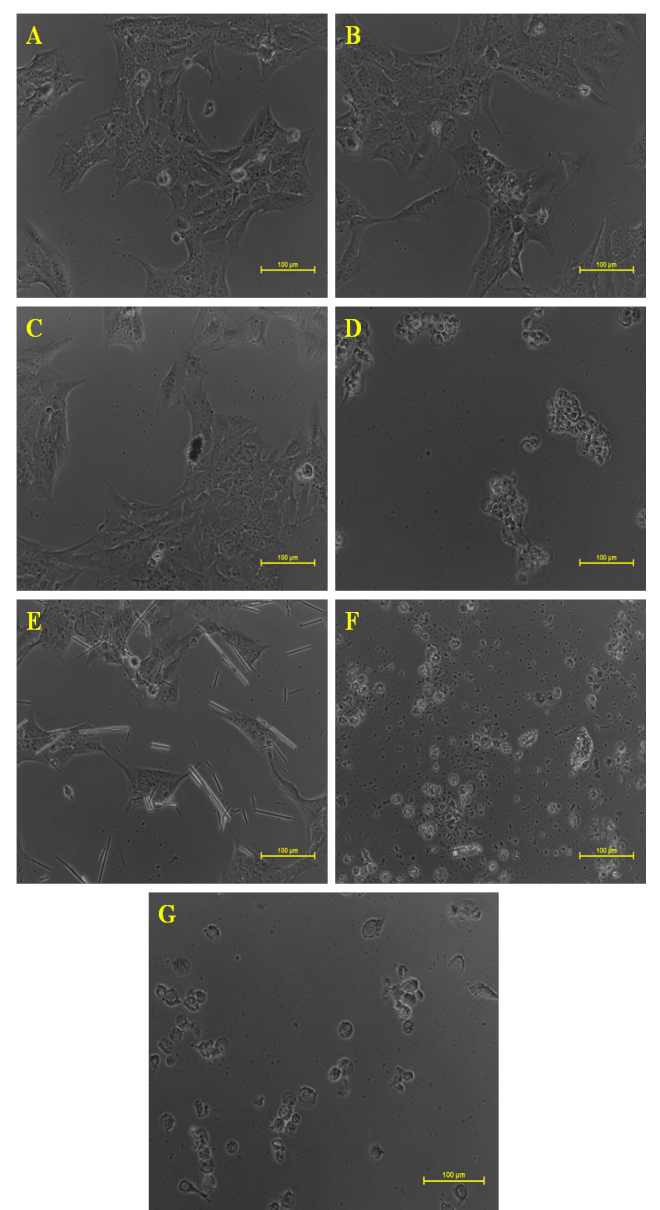

Figure 2 Morphology of the Endometrial Adenocarcinoma cancer cell lines (Ishikawa) in-vitro.

A: Phase-contrast photography of Ishikawa cell lines.

B: Phase-contrast photography of Ishikawa cell lines with Rutin.

C: Phase-contrast photography of Ishikawa cell lines with Stigmasterol.

D: Phase-contrast photography of Ishikawa cell lines with Caffeic acid.

E: Phase-contrast photography of Ishikawa cell lines with Oleanolic acid.

F: Phase-contrast photography of Ishikawa cell lines with Ursolic acid.

G: Phase-contrast photography of Ishikawa cell lines with adriamycin.

Table 5 Drug concentrations $(\mu \mathrm{g} / \mathrm{ml})$ calculated from graph on Ishikawa cell lines

\begin{tabular}{llll}
\hline Ishikawa & LC50 & TGI & GI50* \\
\hline Rutin & NE & NE & $>80$ \\
Stigmasterol & NE & NE & $>80$ \\
Caffeic Acid & $>80$ & 69.7 & 47 \\
Oleanolic Acid & NE & NE & $>80$ \\
Ursolic Acid & NE & 37.2 & $<10$ \\
Adriamycin & NE & 12.7 & $<10$ \\
\hline
\end{tabular}

LC50, Concentration of drug causing 50\% cell kill; GI50, Concentration of drug causing $50 \%$ inhibition of cell growth; $\mathrm{TGl}$, Concentration of drug causing total inhibition of cell growth; NE, Non-evaluable data. Experiment needs to be repeated using different set of drug concentrations
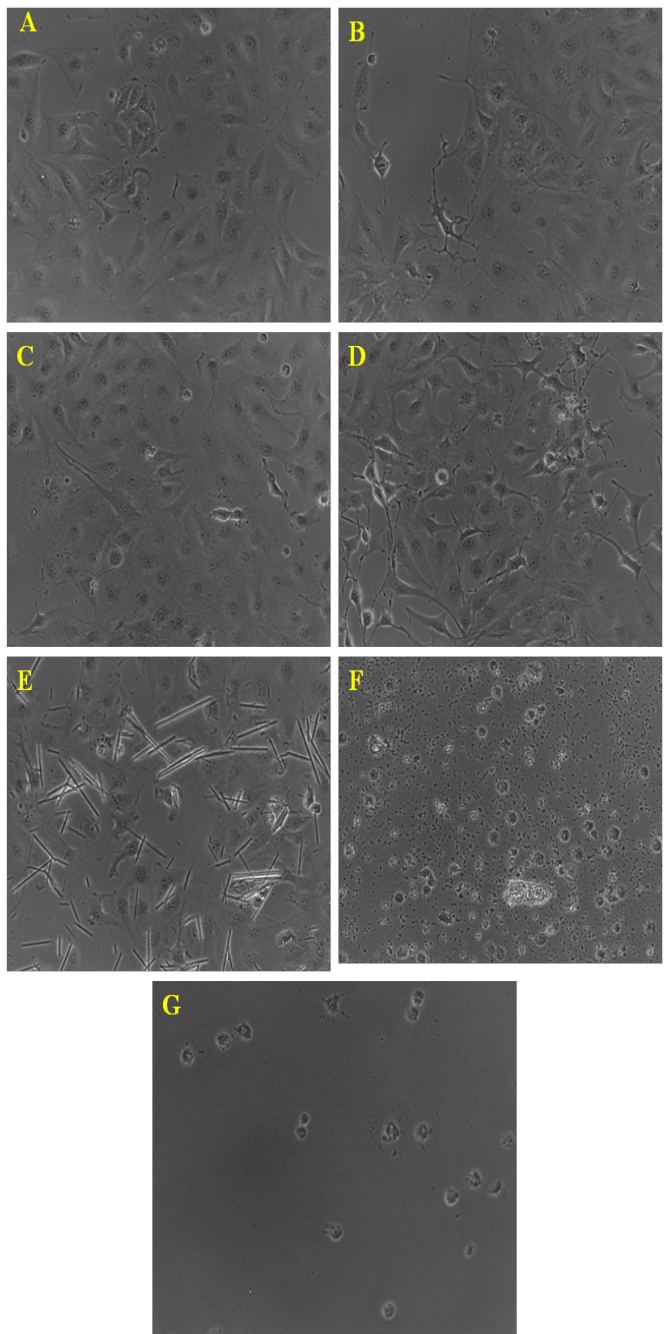

Figure 3 Morphology of the Oral cancer cell lines (SCC-29B) in-vitro. A: Phase-contrast photography of SCC-29B cell lines.

B: Phase-contrast photography of SCC-29B cell lines with Rutin.

C: Phase-contrast photography of SCC-29B cell lines with Stigmasterol.

D: Phase-contrast photography of SCC-29B cell lines with Caffeic acid. E: Phase-contrast photography of SCC-29B cell lines with Oleanolic acid. F: Phase-contrast photography of SCC-29B cell lines with Ursolic acid. G: Phase-contrast photography of SCC-29B cell lines with adriamycin

Table 6 Drug concentrations $(\mu \mathrm{g} / \mathrm{ml})$ calculated from graph on Ishikawa cell lines

\begin{tabular}{llll}
\hline SCC-29B & LC50 & TGI & GI50* \\
\hline Rutin & NE & NE & NE \\
Stigmasterol & NE & NE & NE \\
Caffeic Acid & NE & NE & $>80$ \\
Oleanolic Acid & NE & NE & $\mathrm{NE}$ \\
Ursolic Acid & 60.17 & $<10$ & $<10$ \\
Adriamycin & $\mathrm{NE}$ & $<10$ & $<10$ \\
\hline
\end{tabular}

LC50, Concentration of drug causing $50 \%$ cell kill; GI50, Concentration of drug causing $50 \%$ inhibition of cell growth;TGl, Concentration of drug causing total inhibition of cell growth; NE, Non-evaluable data. Experiment needs to be repeated using different set of drug concentrations 


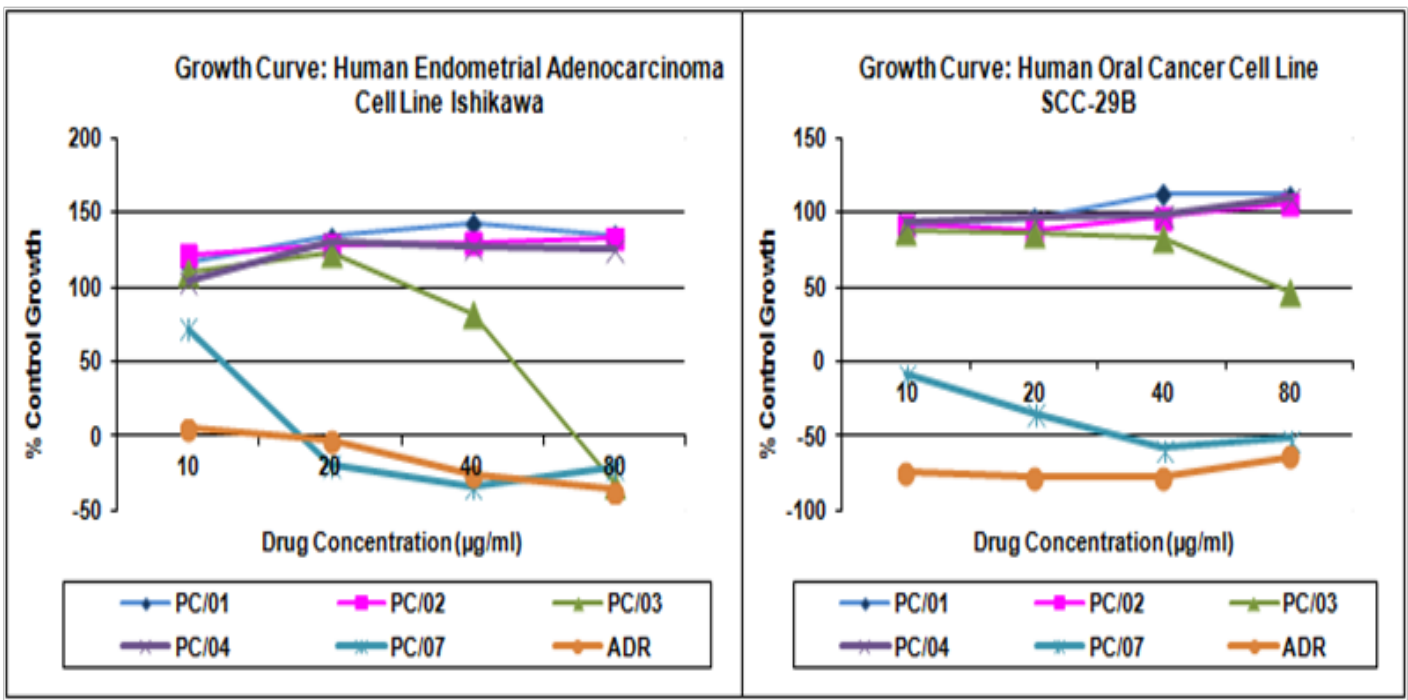

Figure 4 Ishikawa and SCC-29B cell line growth curve.

\section{Conclusion}

The outcome attained from the current investigation signifies that the both plants owned a considerable anticancer activity may be attributed to the presence of isolated constituents i.e., Ursolic acid from Aralia racemosa $L$ and Caffeic acid from Argyreia pilosa, indicating the traditional relevance of the plant, which were non toxic to normal cells. The results of the study will also need to be confirmed using in vivo models and to determine the other active chemical constituents accountable for the anticancer activity.

\section{Acknowledgements}

This work was a part of the Ph.D. thesis of DSNBK. Peasant under the guidance of Dr. A Srinivasa Rao and Y Rajendra Prasad in JNTUK, Kakinada and we extend our sincere thanks to Dr. A Lakshmana Rao, Principal, and management of V. V. Institute of Pharmaceutical Sciences, Gudlavalleru, Andhra Pradesh, for providing the research facilities.

\section{Conflict of interest}

The author declares no conflict of interest.

\section{References}

1. da Rocha AB, Lopes RM, Schwartsmann G. Natural products in anticancer therapy. Curr Opin Pharmacol. 2001;1(4):364-369.

2. Clement JA, Clement ES. The medicinal chemistry of genus Aralia Curr Top Med Chem. 2014;14(24):2783-2801.

3. Clement JA, Flood MJ, Bleich RM, et al. Diterpenoids and acetylenic lipids from Aralia racemosa. Biochem Syst Ecol. 2013;51:4-7.

4. Duke JA. Handbook of medicinal herbs. 2nd ed. USA: CRC Press 2002. 896 p.

5. Quattrocchi U. CRC world dictionary of medicinal and poisonous plants: common names, scientific names, eponyms, synonyms, and etymology. USA: CRC Press; 2012. 3960 p.

6. McCune LM, Johns T. Antioxidant activity in medicinal plants associated with the symptoms of diabetes mellitus used by the indigenous peoples of the North American boreal forest. J Ethnopharmacol. 2002;82(2-3):197-205
7. McCune LM, Johns T. Symptom-Specific Antioxidant Activity of Boreal Diabetes Treatments. Pharm Biol. 2003;41(5):362-370.

8. Grange JM, Davey RW. Detection of antituberculous activity in plant extracts. J Appl Bacteriol. 1990;68(6):587-591.

9. Prasanth DSNBK, Rao AS, Prasad YR. Hepatoprotective activity of Aralia racemosa L. and its Triterpenoid and Steroid Compounds against Paracetamol-Induced Liver Injury in Albino Wistar Rat. Global Journal of Medical Research. 2017;17(2-B):29-42.

10. Marles RJ, Farnsworth NR. Antidiabetic plants and their active constituents. Phytomedicine. 1995;2(2):137-189.

11. Ghorbani A, Langenberger G, Feng L, et al. Ethnobotanical study of medicinal plants utilised by Hani ethnicity in Naban river watershed national nature reserve, Yunnan, China. J Ethnopharmacol. 2011;134(3):651-667.

12. Galani VJ, Patel BG. Psychotropic activity of Argyreia speciosa roots in experimental animals. Ayu. 2011;32(3):380-384.

13. Lalan BK, Hiray R, Ghongane B. Evaluation of Analgesic and Anti-Inflammatory Activity of Extract of Holoptelea Integrifolia and Argyreia Speciosa in Animal Models. J Clin Diagn Res. 2015;9(7):FF01-FF04.

14. Motawi TK, Hamed MA, Hashem RM, et al. Protective and therapeutic effects of Argyreia speciosa against ethanol-induced gastric ulcer in rats. Z Naturforsch C. 2012;67(1-2):47-57.

15. Adate PS, Parmesawaran S, Chauhan Y. In vitro Anthelmintic Activity of Stem Extracts of Piper betle Linn Against Pheritima Posthuma. Pharmacognosy Journal. 2012;4(29):61-65.

16. Alam F, Najum us Saqib Q. Pharmacognostic standardization and preliminary phytochemical studies of Gaultheria trichophylla. Pharm Biol. 2015;53(12):1711-1718.

17. Harborne JB. Phytochemical methods: a guide to modern techniques of plant analysis. UK: Chapman \& Hall; 1998. 302 p.

18. Khandelwal KR, Khandelwal J, Gokhle SB, et al. Practical pharmacognosy: techniques and experiments. Niral Prakashan, Maharashtra, India; 2008.

19. Kokate C. Practical pharmacognosy. Vallabh Prakashan, New Delhi, India; $1986.111 \mathrm{p}$.

20. Patil P, Venkatanarayanan R, Argade P, et al. Assessment of pharmacognostic and phytochemical standards of Thespesia populnea (L.) root. Asian Pac J Trop Biomed. 2012;2(3):S1212-S1216. 
21. Raaman N. Phytochemical techniques. Pitam Pura, New Delhi, India; 2006

22. Roy S, Acharya R, Harisha C, et al. Macro, Microscopic and Preliminary Analytical Evaluation of Root and Leaf of Globba Marantina Linn.-An Extrapharmacopoeial Drug of Ayurveda. Indian J Pharm Sci. 2016;78(4):469-478.

23. Singh P, Khosa RL, Mishra G, et al. Pharmacognostical evaluation of aerial parts of Graptophyllum pictum (L.) Griff. (Syn: Justicia picta Linn.): A well-known folklore medicinal plant. Anc Sci Life. 2015;34(4):223-229.

24. Hossain MA, Ismail Z. Isolation and characterization of triterpenes from the leaves of Orthosiphon stamineus. Arabian Journal of Chemistry. 2013;6(3):295-298.

25. Vasconcelos MAL, Royo VA, Ferreira DS, et al. In vivo analgesic and anti-inflammatory activities of ursolic acid and oleanoic acid from Miconia albicans (Melastomataceae). Z Naturforsch C. 2006;61(78):477-482.

26. Rajput AP, Rajput TA. Isolation of stigmasterol and $\beta$-sitosterol from chloroform extract of leaves of Corchorus fascicularis Lam. Int J Biol Chem. 2012;6(4):130-135.

27. Park HY, Nam MH, Lee HS, et al. Isolation of caffeic acid from Perilla frutescens and its role in enhancing $\gamma$-glutamylcysteine synthetase activity and glutathione level. Food Chem. 2010;119(2):724-730.

28. Vichai V, Kirtikara K. Sulforhodamine B colorimetric assay for cytotoxicity screening. Nat Protoc. 2006;1(3):1112-1116.
29. Skehan P, Storeng R, Scudiero D, et al. New colorimetric cytotoxicity assay for anticancer-drug screening. J Natl Cancer Inst. 1990;82(13):1107-1112.

30. Torricelli P, Antonelli F, Ferorelli P, et al. Antiproliferative activity of a dietary supplement on estrogen receptor positive and negative human breast adenocarcinoma cell lines. Cancer Research Journal. 2014;2(2):29-32.

31. Sun M, Estrov Z, Ji Y, et al. Curcumin (diferuloylmethane) alters the expression profiles of microRNAs in human pancreatic cancer cells. Mol Cancer Ther. 2008;7(3):464-473.

32. Rao GV, Kumar S, Islam M, et al. Folk medicines for anticancer therapy-a current status. Cancer Ther. 2008;6(2):913-921.

33. Subhadradevi V, Asokkumar K, Umamaheswari M, et al. Antimicrobial Activity of Leaves and Flowers of Cassia auriculata linn. Bangladesh journal of scientific and industrial research. 2011;46(4):513-518.

34. Gali K, Ramakrishnan G, Kothai R, et al. In-vitro anti-cancer activity of methanolic extract of leaves of Argemone mexicana Linn. Int $J$ Pharm Tech Res. 2011;3(3):1329-1333.

35. Kumar ASG, Javvadi RK, Kumar VK, et al. Effect of methanolic extract of Adenanthera pavonina Linn on Dalton's ascitic lymphoma. Indian journal of research in pharmacy and biotechnology. 2013;1(1):138141.

36. Clement JA, Willis TJ, Kelly RM, et al. Antitumor Activity of Aralia racemosa. Planta Med. 2009;75:97. 